\title{
Transboundary Aquifers: Conceptual Models for Development of International Law
}

\author{
by Yoram Eckstein ${ }^{1}$ and Gabriel E. Eckstein ${ }^{2}$
}

\begin{abstract}
More than one-half of the world's population is dependent on ground water for everyday uses such as drinking, cooking, and hygiene. In fact, it is the most extracted natural resource in the world. As a result of growing populations and expanding economies, many aquifers today are being depleted while others are being contaminated. Notwithstanding the world's considerable reliance on this resource, ground water resources have long received only secondary attention as compared to surface water, especially among legislatures and policymakers. Today, while there are hundreds of treaties governing transboundary rivers and lakes, there is only one international agreement that directly addresses a transboundary aquifer. Given that many of the aquifers on which humanity so heavily relies cross international borders, there is a considerable gap in the sound management, allocation, and protection of such resources. In order to prevent future disputes over transboundary aquifers and to maximize the beneficial use of this resource, international law must be clarified as it applies to transboundary ground water resources. Moreover, it must be defined with a firm basis in sound scientific understanding. In this paper we offer six conceptual models is which ground water resources can have transboudary consequences. The models are intended to help in assessing the applicability and scientific soundness of existing and proposed rules governing transboundary ground water resources. In addition, we consider the development of international law as it applies to ground water resources and make recommendations based on the models and principles of hydrogeology. The objective is the development of clear, logical, and science-based norms of state conducts as they relate to aquifers that traverse political boundaries.
\end{abstract}

\section{Introduction}

Over the past half-century, ground water has emerged as a vital source of water for millions of people worldwide (McCaffrey 1991). More than one-half of the world's population today is dependent on ground water for its basic needs (UN 2003). Among European nations, at least $75 \%$ of drinking water comes from ground water; in Austria, Croatia, Denmark, Hungary, Italy, Lithuania, and Slovenia, it exceeds 90\% (Almássy and Busás 1999). In the United States, ground water provides

Corresponding author: Professor of Hydrogeology, Department of Geology, MG-211, Kent State University, Kent, OH 44242

${ }^{2}$ Associate Professor of Law, Director, Center for Water Law \& Policy, Texas Tech University School of Law, 1802 Hartford Avenue, Lubbock TX 79409

Received February 2005, accepted March 2005.

Copyright @ 2005 National Ground Water Association. doi: 10.1111/j.1745-6584.2005.00098.x approximately one-half of all drinking water; in rural areas of the country, the percentage is as high as $97 \%$ (Murray and Reeves 1977; Burchi 1999). Expanded reliance on ground water as a chief source of fresh water is due in large part to the growth in industry, agriculture, and the global population (Hayton and Utton 1989). In the past 100 years, per capita global water consumption grew ninefold; presently, human water use is increasing $4 \%$ to $8 \%$ annually (Dellapenna 2001). Coupled with improvements in ground water management technology, ground water use has escalated from meeting strictly local needs to providing for whole nations (UN 2003).

As dependence on ground water resources increases globally, a host of new questions and problems arise relating to ownership, use, access, protection, and development of ground water resources, especially in border areas where such water resources traverse international political boundaries (Hayton and Utton 1989). These issues have become increasingly important in the transboundary context primarily because there is scarcely 
a country in the world (except for most island nations) not linked hydrologically to another country (Teclaff and Teclaff 1979; Almássy and Busás 1999). As a result, there is now a growing need for the clarification and progressive development of international law as it applies to ground water resources (Mumme 2000). In particular, with ground water consumption reaching and even exceeding sustainable withdrawals in many parts of the world and in order to avoid future disputes and maximize beneficial use of this shared but finite resource, there is a need to clarify the rights and obligations that states enjoy vis-à-vis transboundary and international ground water resources.

This article focuses on ground water resources that traverse an international political boundary between two or more sovereign states or that are hydraulically connected to surface water that traverse such a boundary. The phrases "transboundary aquifer" and "transboundary ground water" are used in this article to refer solely to ground water that traverses a political boundary between two or more sovereign states. The term "international aquifer" is used to describe an aquifer that is part of a system that, at some point, traverses an international political boundary, like, for example, a purely domestic aquifer hydraulically linked to a transboundary river.

Barberis (1986), in a study for the United Nations Food and Agriculture Organization (FAO), offered four case models to demonstrate the various transboundary implications associated with ground water resources. These case models were designed as generic paradigms for the application of international water law. Moreover, they were intended to aid in clarifying the standards and principles of international law applicable to transboundary and international ground water resources. While the underlying premise of Barberis' case models - that ground water resources can have substantial international implications - is correct, and although the FAO study has been widely cited (including in the proceedings of the United Nations International Law Commission [LC], which drafted the 1997 United Nations Convention on the Law of the Non-Navigational Uses of International Watercourses), two of the case models are flawed. Moreover, the four case models do not fully account for all of the common aquifer types that exist in nature with transboundary implications.

In this paper, we treat transboundary and international ground water resources under international law from a hydrogeologic perspective by considering the shortcomings of Barberis' four models and by offering six new conceptual models in which ground water resources have transboundary consequences. The models are intended to help in assessing the applicability and scientific soundness of existing and proposed rules governing transboundary and international ground water resources. Consequently, they should aid in developing clear, logical, and science-based norms of state conduct as they relate to transboundary and international ground water resources. Last, we consider in this paper the development of international water law as it applies to ground water resources and make recommendations based on the models and principles of hydrogeology.

\section{History of Ground Water under International Law}

Ground water resources historically have been omitted from, or neglected under, international law and cursorily misunderstood within the legal community (Utton 1982; Caponera and Alhéritière 1978; Hayton 1981). While agreements focusing on transboundary rivers and lakes are relatively common (Caponera 1992), there is a paucity of treaties and norms addressing transboundary and international ground water resources (Caponera and Alhéritière 1978). This, in turn, often causes a disregard for ground water resources in projects that have transboundary and ground water implications.

English Common Law treated ground water either as part of the overlying land or as a commodity, subject to its capture (i.e., via a well). It was also subject to absolute ownership by the superadjacent property owner (Utton 1982). Under the French Civil Code, a landowner could make full use of springs located on his property so long as he did not affect the lands of his neighbors (Caponera and Alhéritière 1978). Spanish law, which influenced much of ground water law in Latin America and the Philippines, treated ground water similarly to the English Common Law but added the more progressive concept that ground water underlying public lands constitutes public ground water (Hayton 1981). Nevertheless, ground water under these legal regimes was rarely, if ever, considered in conjunction with related surface water or made subject to the same regulatory or management scheme.

Islamic legal tradition may have one of the richest traditions of law applicable to ground water resources. Over the generations, an extensive priority of rights to water access and use developed, including a right to drink, to water domestic animals, to irrigate land, and to share for other needs (Caponera and Alhéritière 1978). Indeed, Islam considers the sharing of water a holy duty under Islam. Like the Western legal systems, however, the Islamic legal tradition rarely considered ground water contemporaneously with surface water and does not address transboundary ownership and allocation issues (Civic 1998).

References to ground water resources, in the form of wells and springs, can be found in international treaties dating to the 19 th and early 20 th centuries, albeit typically only as a secondary (or even tertiary) issue: the 1888 agreement between the United Kingdom (for Somalia) and France (for Djibouti) affords both parties common rights to use the Hadou well; the Versailles Treaty ending World War I, in the delimitation of the common border between Germany and Belgium, refers to the use of springs and ground water; the 1923 exchange of notes between France (for Syria) and the United Kingdom (for Palestine) addresses the use of spring water; and the 1924 exchange of notes between France and the United Kingdom briefly addresses the use of surface and spring water between the Central African Empire, Chad, and Sudan. A number of early agreements dealing with mining activities in border regions also briefly refer to the use of ground water resources: the 1843 agreement between Belgium and Luxembourg concerning mining and the 1934 agreement between 
Tanganyika and Ruanda Urundi concerning water rights on the boundary (Caponera and Alhéritière 1978).

Early in the 20th century, as the importance of ground water resources began gaining recognition, treaties of cooperation and resolutions of transboundary dispute began referencing aquifers and ground water in the border regions but again only as a secondary issue and often in passing (Utton 1982). Among these are the 1925 agreement between Egypt and Italy on the Ramba Well; the 1927 Convention and Protocol between the USSR and Turkey, which concerned the use of frontier water; and the 1947 treaty of peace between the Allies and Italy, which concerned the use of springs in the Commune of Gorizia and vicinity by Italy and Yugoslavia.

As governments and policymakers became more knowledgeable about the science of water, international agreements began recognizing the interrelationship between surface and ground water. For example, the 1950 treaty between the German Federal Republic and Luxembourg provides that "in the event of damage caused by a rise or fall in the ground water on the west side of the Sauer in consequence of the construction of the dam, the government of the Grand Dutchy of Luxembourg undertakes to rectify such damage or pay appropriate compensation." Recognition of jurisdiction over transboundary aquifers by boundary commissions and boundary water institutions began appearing in international treaties. For example, such recognition appeared in various treaties between Yugoslavia and its neighbors; between Poland and Czechoslovakia (1958) over the use of water resources in the frontier region; between Cameroon, Chad, Niger, and Nigeria (1964) over the development of the Chad Basin; between Finland and Sweden (1972) over water resources in the frontier; between Italy and Switzerland (1972) regarding management of water pollution; and between the United States and Mexico (1973) over the salinity of the Colorado River.

The 1977 agreement signed between the French Prefect de Haute-Savoie and the Swiss Canton of Geneva concerning ground water resources in the Lake Geneva basin is the only international agreement that directly addresses transboundary aquifers (Wohlwend 2002). This, relatively simple agreement, addresses both water extraction and artificial recharge for the rational management of the aquifer and is unique because the parties arranged it at a local, rather than international, level.

Despite these references and the growing acknowledgment of the significance of ground water resources, agreements concerning ground water and the development of international law applicable to transboundary aquifers are limited (Caponera 1992). While states are making greater efforts to address this situation, a lack of consensus regarding the applicable international law to transboundary and international ground water resources still exists (Fuentes 1999; Dellapenna 2001).

The International Law Association Helsinki Rules of 1966 and Seoul Rules of 1986 (International Law Association [ILA] 1966, 1986) represent some of the earliest efforts to formally and directly address the status of transboundary and international ground water resources under international law. Article II of the Helsinki Rules defines an international drainage basin, the unit used to delineate the geographic scope considered under the rules, as a transboundary geographic area defined by the extent of the watershed. This definition includes "surface and groundwater." The Seoul Rules reinforced and expanded the Helsinki Rule that ground water is a proper subject of international law by including all types of aquifers (Eckstein 1995). While the development of these two rules suggests progress in the evolution of international norms and principles for transboundary aquifers, their application has had limited influence on state practice and treaty development because the ILA is a private nongovernmental organization with no official authority to formulate international law (Dellapenna 1992/1994).

The 1997 Convention on the Non-Navigational Uses of International Watercourses (UN 1997) is a unique milestone in the development of international law related to ground water resources. While crafted to articulate the law of "international watercourses," the convention defines watercourse as "a system of surface waters and ground waters constituting by virtue of their physical relationship a unitary whole and normally flowing into a common terminus." This definition supports the doctrine of hydrological unity and acknowledges the important self-relationship of surface and ground water within the hydrological cycle (Eckstein and Eckstein 2003). For the definition to apply in the international context, it is not necessary for an aquifer to traverse an international boundary so long as a hydraulically related river traverses or flows along an international border (McCaffrey 1999).

Thus, under the Watercourse Convention, the international norms and principles applicable to surface water resources also apply to all transboundary and international ground water. The most notable principles are reasonable and equitable use, no substantial harm, cooperation, and good faith negotiations.

Despite this progress, the Watercourse Convention is not a comprehensive elucidation of the status of ground water under international law. In fact, the scope of the document may raise more questions than provide answers about the status of ground water resources under international law. Some unclear areas include the justification for differentiating between various aquifer types and the applicability of international law to particular aquifer types. For example, the broad definition of "watercourse" imposes very specific limitations on the scope of the convention. Therefore, not all types of aquifers fall under the rubric of the Watercourse Convention.

\section{Conceptual Models of Ground Water Resources with Transboundary Implications}

Like surface water, ground water has no political boundary. Ground water is usually part of a greater hydrologic system, sometimes with the surface or ground water of neighboring states. It is rare that a transboundary river is not linked to a domestic or transboundary aquifer.

Spatial demarcations of frontiers and borders serve as the basis for states' territorial rights. For example, 
solid mineral deposits that extend across borders are divided based on these spatial demarcations. However, this division of rights is inadequate in the case of fluid deposits, such as ground water, because none of the sharing states can determine the precise amount of ground water accruing to them without the assistance of the other riparian states. Even with the assistance of other states, it is difficult to reliably identify the exact dimensions and contents of an aquifer because of the fluid and dynamic nature of ground water.

In addition, with some exceptions, most aquifers regularly receive and transmit water as part of the hydrologic cycle, thus directly affecting both the quantity and quality of the water in the aquifer. Contamination of any part of a water cycle in a given environmental system will eventually affect the quality of water within the entire aquatic system. This is not to say that all aquifers are interconnected with surface water. Nevertheless, there is an interdependent relationship between the majority of surface and ground water resources that requires a comprehensive perspective for their use, management, and conservation. Because of the transboundary and international characteristics of so many aquifers, ground water is a proper subject of international law.

Barberis (1986) offers four case models to illustrate the transboundary and international nuances associated with ground water resources:

1. A confined aquifer that is intersected by an international boundary and is not linked hydraulically with other ground water or surface water, and, as such, it alone constitutes the shared natural resource.

2. An aquifer that lies entirely within the territory of one state but is hydraulically linked with an international river.

3. An aquifer that is situated entirely within the territory of a single state and is linked hydraulically with another aquifer in a neighboring state.

4. An aquifer that is situated entirely within the territory of a given state but has its recharge zone in another state.

In presenting these models, Barberis sought to clarify both the international implications of transboundary and international ground water resources and the legal status of this hidden resource under international law. Barberis intended the case models to illustrate transboundary and international aquifers found in nature and to be used as models for the application of international legal norms. While Barberis was correct in suggesting that ground water resources can have substantial international implications, two of the case models presented are scientifically imprecise and require further refinement and clarification.

Barberis' first example lacks precision in that it lumps together all unrelated confined aquifers under one example. As we discuss subsequently, unrelated confined aquifers must be subdivided into two categories based on their relationship to the hydrologic cycle: those that constitute a dynamic component of the hydrologic cycle (despite being unrelated to any other body of water) and those that are connate static bodies of water devoid of any connection to a source of recharge. The basis for this categorization is important to the extent that international law applicable to these two aquifer types may not necessarily be the same. The Watercourse Convention, for example, excludes unrelated confined aquifers from its scope and applies only to aquifers directly related to a surface body of water. Moreover, as we will discuss subsequently, a static body of water unconnected to the hydrologic cycle may not be subject to the same legal regime as is applicable to surface water.

Furthermore, to the extent that this case model suggests that a substantial hydraulic link can exist between two distinct but adjacent aquifers, the case model is inconsistent with the science of ground water. Any "link" described between two adjacent aquifers is necessarily a component of both aquifers. Rather than two "linked" aquifers, the example would implicate one heterogeneous transboundary aquifer. Even in the relatively uncommon case where fractures spread laterally across an international boundary connecting two aquifer sections located on opposing sides of the border, the reality is that the aquifer sections are one heterogeneous aquifer composed of three interrelated lateral units (the two aquifer sections and the fractured rocks between). To the extent that Barberis' second case model also describes two separate but hydraulically linked aquifers, it too is scientifically inaccurate.

Barberis intended the four case models to be representative of the main cases in which ground water resources have transboundary implications. As briefly noted previously, the cases require reconsideration and refinement, in part because of their scientific inaccuracy, but also because Barberis' list is incomplete. The four case models do not account fully for other common aquifer types that have possible transboundary implications, including aquifers that are unconfined and unrelated to another water resource, those that are confined and unrelated to another water resource, and those that are nonrenewable. However, Barberis' models should not be discounted as they still provide a useful starting point from which to develop more refined and precise models of transboundary and international aquifers that incorporate principles of hydrogeology and that are based on actual examples.

Accordingly, we propose the following six conceptual models as illustrative of the main scenarios in which ground water resources can have transboundary implications. While they do not encompass the entire realm of hydrogeological possibilities, the models are representative of the vast majority of aquifers existing on the earth. More importantly, they provide an opportunity to test, evaluate, and refine existing and proposed principles of international law on scientifically valid generic models.

\section{Model A}

Model A (Figure 1) depicts an unconfined aquifer that is linked hydraulically with a river (either losing or gaining), both of which flow along an international border (i.e., the river forms the border between two states). Because of the hydrologic connection between the 


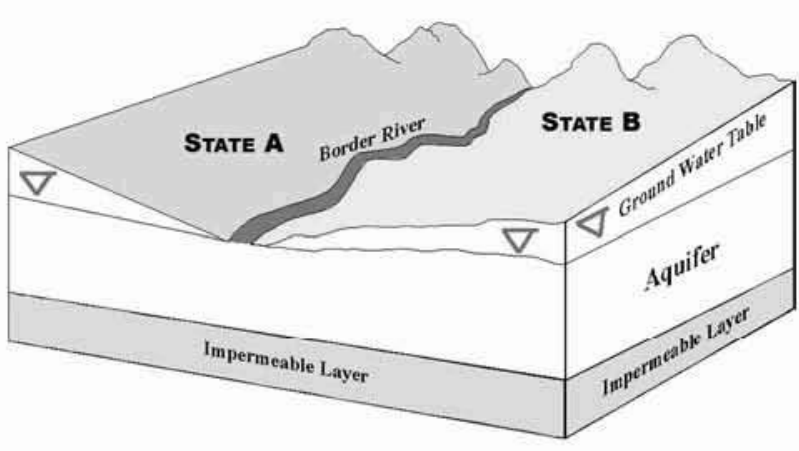

Figure 1. Model A.

transboundary aquifer and the transboundary river, the ground water in this model would be subject to the Watercourse Convention and the principles and norms contained therein.

While the aquifer constitutes one body of water, the two related sections on either side of the border river have little or no direct effect on each other. Regardless of whether the river is gaining (as shown in Model A) or losing, water flow between the two sections is limited by the hydraulic gradient. Thus, any negative characteristic (such as pollution) found in one of the aquifer sections is unlikely to affect the other section, and therefore there is no transboundary relationship between the two aquifer sections. An exception to this, however, can occur when one of the nations sharing the aquifer overpumps the section underlying its territory. If the resulting cone of depression extends to, and possibly even across, the river, the overpumping state will also draw water from the aquifer section underlying the nonpumping state. In addition to possible problems of depletion, any negative characteristics found in the section underlying the nonpumping state (e.g., pollution) could be transported by the flow to the section underlying the pumping state.

Another transboundary consequence implicated by this model concerns the relationship of the aquifer to the border river. To the extent that the river is gaining (as depicted in Model A), water will flow from the aquifer into the river. Thus, any negative characteristics found, or introduced, in one or both of the aquifer sections will impact the river, although, as noted previously, not the other aquifer section. Because the river forms the border between the two states, the impact is by definition international. Similarly, any negative characteristic found in a losing river could impact both sections of the aquifer, again resulting in transboundary consequences. Of course, a river can be losing and gaining at different points along its course with the same aquifer, based on topography, precipitation, and soil hydraulic conductivity. Moreover, such losing and gaining relationships are often subject to climatic conditions and can change with the seasons. As a result, these conditions create more complex scenarios in which transboundary consequences could manifest.

Examples of this model include the Red Light Draw, Hueco Bolson, and Rio Grande aquifers underlying the United States and Mexico (Hibbs et al. 1998; International Boundary and Water Commission 1998). All three of the aquifers are unconfined, directly related to the Rio Grande, and flow along the border between the state of Texas in the United States and the state of Chihuahua in Mexico. Another example for this model is the Danube alluvial aquifer underlying the portion of the Danube River flowing between Croatia and Serbia (Mijatovic 1998).

\section{Model B}

Model B (Figure 2) shows an unconfined aquifer intersected by an international border and linked hydraulically with a river that is also intersected by the same international border. It differs from the first model because the political boundary bisects both the river and the related aquifer rather than following the course of the river. Similar to the situation in Model A, this model also falls within the scope of the Watercourse Convention because of the hydrologic connection between the transboundary aquifer and the transboundary river.

Generally, gradients explain the transboundary consequences implied by this model. Water in the river and the related aquifer flows down-slope from State A to State B, therefore implying that most transboundary situations will result from pollution in State A transported into State B (through either the river or the aquifer) or from overpumping in State A, which reduces the flow into State B. Nevertheless, excessive pumping in either state could have limited local transboundary consequences. For example, depending on the size of the cone of depression surrounding a pumping well located in State A, in addition to problems of depletion, State A could inadvertently pump any negative characteristic found in the aquifer underlying State B (the nonpumping state) into State A.

In addition, like the situation in Model $\mathrm{A}$, the relationship between the two aquifer sections (on either side of the river) will be limited except to the extent that the river's gaining or losing relationship with the underlying aquifer changes along the course of the river. If the river is gaining upstream in State A and losing downstream in State B, any negative characteristic (such as pollution) found in one of the aquifer sections in State A could flow into the river and then into the aquifer on both sides of the river in State B.

Examples of this model include the AbbotsfordSumas Aquifer traversing the border between Canada and the United States (Abbotsford-Sumas Aquifer International Task Force n.d.) and is hydraulically related to

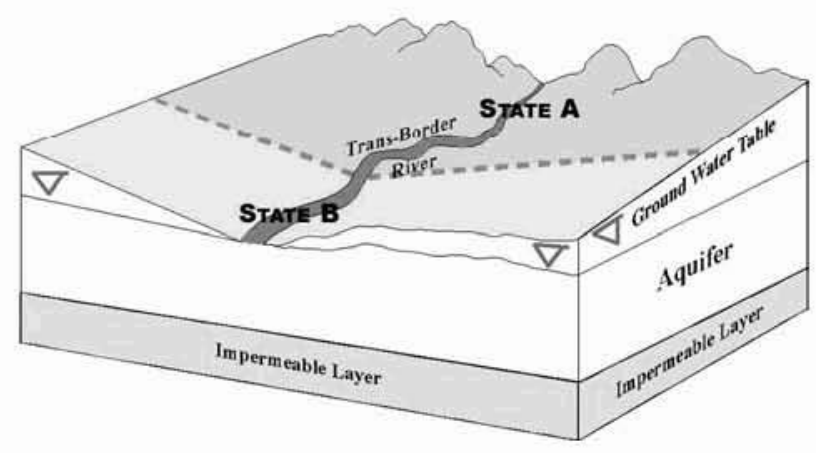

Figure 2. Model B. 
the Sumas River and Bertrand and Fishtrap creeks, all of which flow from Canada into the United States; the Mures/Maros Aquifer underlying Hungary and Romania, where the unconfined aquifer is related directly to the overlying Mures/Maros River, which flows into the Tisza River, a tributary of the Danube River (Anderson 1998); and the San Pedro Basin aquifer traversing the border between Mexico and the United States, where the predominantly unconfined aquifer is linked hydraulically to the San Pedro River, which flows northward into the United States and merges with the Gila River, a major tributary of the Colorado River (Arias 2000).

\section{Model C}

Model C (Figure 3) depicts an unconfined aquifer that flows across an international border and is hydraulically linked to a river that flows completely within the territory of one state. As suggested previously, it appears that for the Watercourse Convention to apply, the transboundary character of an aquifer-river system must be found in the river. Accordingly, this model does not fall within the scope of the convention.

The transboundary implications of this model rely solely on the distribution of the hydraulic potential within the aquifer. Model $\mathrm{C}$ shows a gaining river-aquifer relationship where ground water recharged in State A flows into State B and into the gaining river. As noted previously, this relationship can change at different points along the river based on topography, changes in precipitation rates, and hydraulic conductivity. Thus, depending on the proximity of such variations in relation to the international border, transboundary consequences could also manifest themselves from State B to State A. Furthermore, excessive pumping in State A could result in a cone of depression that would locally reverse ground water flowing from State A to State B in the immediate area of pumping, thus causing any negative characteristic found in the ground water underlying State B to be transported toward the pumping well in State A.

An example of this model is the Mimbres Basin aquifer, an unconfined aquifer in northern Mexico and the southern portion of New Mexico that is recharged by the Mimbres River, which flows solely inside the United States (Hebard 2000).

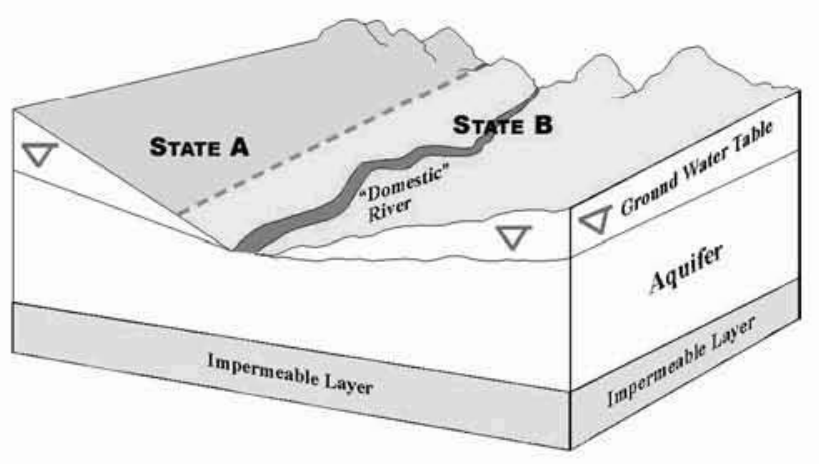

Figure 3. Model C.

\section{Model D}

Model D (Figure 4) shows an unconfined aquifer that is completely within the territory of one state but is linked hydraulically to a river flowing across an international border (in such cases, the aquifer is always located in the "downstream" state). In this model, the river is international, while the aquifer is geographically domestic. As such, this river-aquifer system does fall within the scope of the Watercourse Convention and is plainly described by Barberis' second case model (Barberis 1986).

The transboundary implications for this model are solely dependent on river volume and quality flowing from State A to State B. In this model, State A has the singular opportunity and responsibility for ensuring the quantity and condition of water in the river.

An example of this model is the Mesopotamian Basin of the Tigris and Euphrates rivers. The two rivers have their headwaters in the crystalline massif of southeastern Anatolya in Turkey and flow across international boundaries: the Tigris flows southeast into Iraq, while the Euphrates flows first southward into Syria and then southeast into Iraq. In Iraq, the two rivers flow over the large sedimentary basin of Mesopotamia, forming an aquifer, which, in some places, is as thick as $300 \mathrm{~m}$ (FAO AQUASTAT).

\section{Model E}

Model E (Figure 5), conceptualized in Barberis' fourth case model, describes a confined aquifer, unconnected hydraulically with any surface body of water (except perhaps within the recharge zone in an unconfined portion of the aquifer) that traverses an international boundary or that is located completely in another state. Due to its solitary and unrelated characteristics, it is unlikely that the aquifer in this model could fall within the scope of the Watercourse Convention, which defines "watercourse" as "a system of surface waters and ground waters constituting by virtue of their physical relationship a unitary whole and normally flowing into a common terminus." Thus, the definition of watercourse limits the scope of the Watercourse Convention only to "systems," and only to systems that have a "physical relationship"

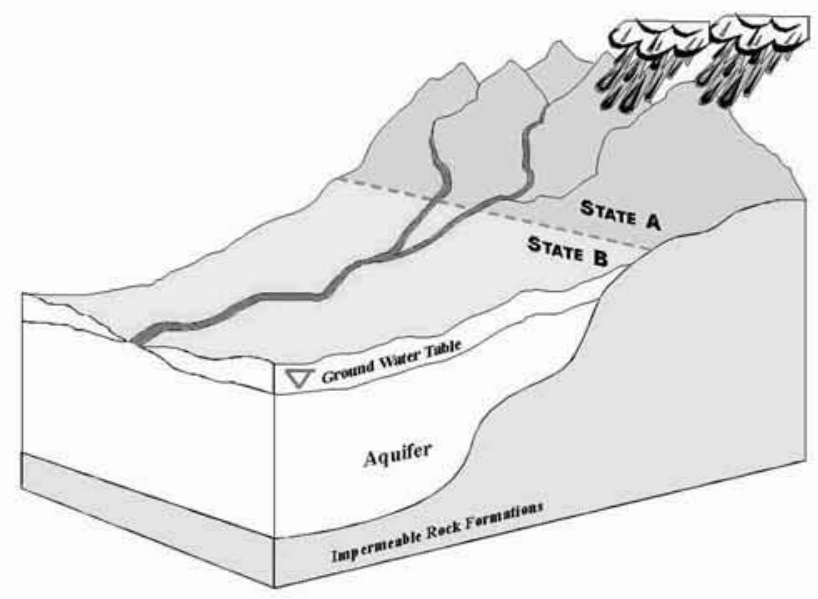

Figure 4. Model D. 


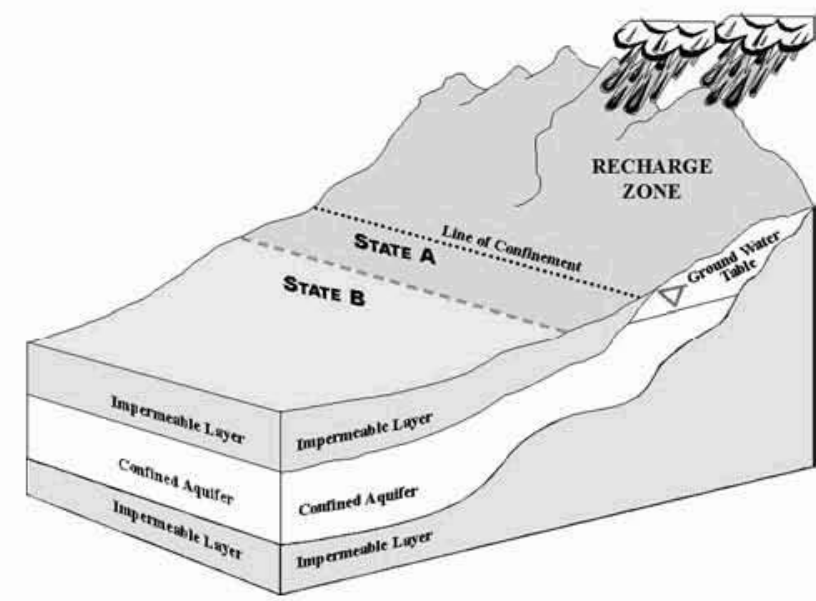

Figure 5. Model E.

between the interlinked components. This begs the questions of whether a single aquifer can constitute a system in and of itself and whether the aquifer's limited interaction within the hydrologic cycle through a recharge zone constitutes, by virtue of this interaction, "a unitary whole" within the scope of the Watercourse Convention.

Notwithstanding the ambiguous status of this model under international law, this type of aquifer can clearly have transboundary consequences. Those consequences are, in large part, a function of the rate of pumping. Any excessive pumping in one or both states could have serious implications for the part of the aquifer along the border between the two countries. Moreover, any negative characteristics found in the aquifer underneath one of the states could be transported to the other as a result of either natural flow (i.e., from State A to State B) or a cone of depression locally reversing the natural flow (within a distance limited by the cone of depression). In addition, the possibility that State A could divert surface runoff from recharging the aquifer or undertake activities that pollute surface water in the recharge zone (i.e., agricultural runoff, untreated municipal and industrial waste) also can implicate international consequences.

Examples of this model include the series of deep, confined aquifers in the Syr Darya River basin of Kazakhstan, which are not linked to the Syr Darya River but which are recharged in the high mountains of Turkmenistan and Tajikistan (Sydykov and Veselov 1993); the "Mountain Aquifer" between Israel and the Palestinian Territory of the West Bank, where the calcareous formations of the Upper Cretaceous (Turonian-Cenomanian) are exposed and recharged in the highlands within the Palestinian regions of Judea and Samaria mountains and slope westward across the Israeli pre-1967 border (so-called green line) toward the Mediterranean Sea and underneath a confining layer (Eckstein and Eckstein 2003); and the Guarani Aquifer underneath Argentina, Brazil, Paraguay, and Unuguay, which is confined in $90 \%$ of its extent (Tujchneider et al. 2003; Kemper et al. 2003).

\section{Model F}

Model F (Figure 6) represents all transboundary aquifers that are unrelated to any surface body of water

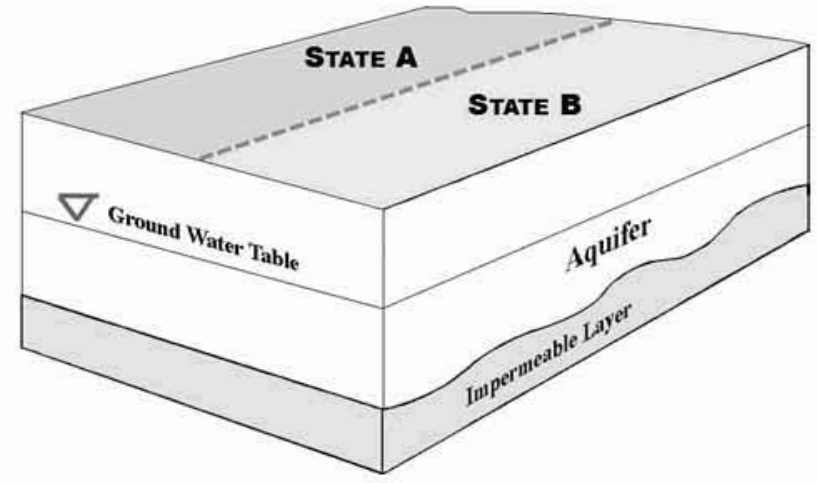

Figure 6. Model F.

and disconnected from the hydrologic cycle, thus devoid of any meaningful recharge. Such aquifers contain ancient water and may be confined or unconfined, as well as fossil or connate (Bouwer 1978). As such, these aquifer types are nonrecharging and cannot be sustainably exploited. Figure 6 depicts one such case of an unconfined aquifer located in an arid zone, where recharge rates are negligible. Examples of such an aquifer include Nubian Sandstone underneath Libya, Chad, Egypt, and Sudan (LaMoreaux et al. 1985; Sultan et al. 2004); the Complex Terminal Aquifer underlying Algeria and Tunisia and possibly extending underneath Libya and Morocco (Krishna and Salman 1999); the Continental Interclaire Aquifer underlying Algeria and Tunisia and possibly Libya and Morocco; and the Qa-Disi Aquifer underlying southern Jordan and northern Saudi Arabia (Krishna and Salman 1999). As there is neither a distinct recharge nor discharge zone (except for evaporation from the exposed water table in oases), the water table in this type of aquifer is quasi-horizontal, and the water is stagnant with little or no perceptible flow. Other cases of transboundary aquifer unrelated to any surface body of water and devoid of any recharge may include a confined aquifer cut off of any possible recharge zones by tectonic displacements or stratigraphic and sedimentary discontinuities.

Due to this unique geologic configuration, the transboundary consequences associated with nonrecharging aquifers are almost exclusively a function of pumping the aquifer in one or more of the overlying states. When a state commences production of ground water from a water well penetrating such an aquifer, the state will generate an ever-expanding cone of depression that will eventually encroach across the international border. Any restrictions on the rates of pumping that are imposed by international law or a treaty between the two (or more) overlying states claiming rights to the water in the aquifer may reduce the rate of the expansion of the cone of depression but will never completely stop it from expanding. Of course, two competing wells on opposite sides of a border will create two cones of depression that will eventually overlap and coalesce, and the rates of expansion of the cones of depression will depend on the particular rates of extraction and hydraulic properties of the aquifer. In either scenario, if the states do not 
completely stop pumping, the aquifer eventually will be fully depleted.

Note that the phreatic aquifer depicted in Figure 6 is uniquely susceptible to pollution because of its stagnant and nonrecharging character. Once such aquifers become polluted, they are extremely difficult, if not impossible, to clean. The absence of recharge and flow to, and within, the aquifer prevents or at least minimizes most of the natural attenuation processes.

As a result of these distinctive qualities, it is unclear whether the principles and norms found in the Watercourse Convention would apply to this aquifer type. Moreover, as we discuss subsequently, questions arise as to whether any of the principles of contemporary international water law apply to such resources.

\section{Nonrenewable Transboundary Ground Water Resources and International Law}

While certain aquifer characteristics may require additional consideration, for the most part, transboundary and international aquifers should be subject to the same rubric of the international law applicable to surface water (Eckstein 1995). In the case of nonrenewable ground water, however, questions arise as to whether the same principles and norms can, and should, govern such aquifer types.

Nonrenewable ground water, as discussed previously, is water contained in nonrecharging aquifers that are detached from the hydrologic cycle. Such aquifers have little or no appreciable natural recharge and usually do not discharge naturally, except for evaporation from oases or occasional springs. By definition, such aquifers cannot be used sustainably, and any continuous withdrawal eventually will exhaust the resource.

One of the few articulations of international law that suggests applying to nonrecharging aquifers the same international law applicable to surface water is the ILA's Seoul Rules (ILA 1987). Supplementing the ILA's Helsinki Rules (ILA 1966), the Seoul Rules provide in article II (2) that "[a]n aquifer intersected by the boundary between two or more States that does not contribute water to, or receive water from, surface waters of an international drainage basin constitutes an international drainage basin for the purposes of the Helsinki Rules." For a hydrogeologist, it is an oxymoron, as one can hardly imagine a confined aquifer cut off from any recharge zone to be considered a contemporary "drainage basin." The nonbinding nature of the rules (as the ILA is a private organization without formal authority to formulate international law), as well as the absence of other similar enunciations, however, limits the authority and weight afforded to this pronouncement as a basis for the development of international law.

The more recent and possibly more authoritative Watercourse Convention excludes nonrecharging aquifers from its scope. Nonrecharging aquifers are, by definition, not part of any "system[s] of surface waters and groundwaters," do not have a "physical relationship" with any other water resources, and do not flow "into a common terminus" (as required by the Watercourse Convention). Furthermore, in comments to the final draft articles of the Watercourse Convention, the ILC, which drafted the principles found in the convention, noted that "[i]t follows from the unity of the system that the term 'watercourse' does not include 'confined' ground water, meaning that which is unrelated to any surface water." While misapplying the hydrogeologic term "confined" to mean "unrelated," the ILC clearly indicated its position that solitary aquifers, such as nonrecharging aquifers, are not subject to the norms and principles of the Watercourse Convention. The ILC rationalized this intentional exclusion on the unscientific and unsubstantiated basis that unrelated ground water could not have any untoward effects on any other watercourse.

It is noteworthy, however, that following the adoption of the text of the draft Watercourse Convention, the ILC adopted a Resolution on Confined Transboundary Groundwater (UN 1994). In the resolution, the ILC pressed states to apply the principles codified in the Watercourse Convention to ground water resources not related to an international watercourse. The inconsistency of the resolution with the Watercourse Convention, however, as well as the lack of definitiveness of the resolution under international law, continues to leave this issue unresolved.

As discussed previously, however, because of their nonrecharging and stagnant character, these aquifers are uniquely susceptible to pollution. The absence of recharge and flow to and within the aquifer makes any contamination extremely difficult, if not impossible, to clean. Moreover, the lack of monitoring and the fact that aquifer contamination often takes decades to manifest bring into question whether states should apply even stricter standards to nonrecharging aquifers than those found in the Watercourse Convention (Yamada 2003).

A number of authors have suggested that the law applicable to nonrenewable ground water may be akin to the law applied to other static, fluidic, depletable substances, such as oil and gas (Caponera 1992; Krishna and Salman 1999). Generally, transboundary oil and gas resources are developed in the context of a cooperative and primarily commercial effort (Székely 1986; Utton and McHugh 1986). In some cases, the sharing states agree on joint management or joint ownership and in other cases, some form of unitization (Pedrazzini and Teyssier 1986). Costs and benefits are often allocated equally, in proportion to the resource located within each state at the time the agreement is concluded or based on some other agreed-upon compromise. Frequently, one company is hired to extract the resources as well as to allocate the costs, proceeds, and resources extracted. The widespread acceptance of such cooperative efforts in the exploration and exploitation of transboundary oil and gas deposits, in some scholars' judgment, has given rise to a customary norm of international law (Utton and McHugh 1986).

Given the physical similarities of nonrenewable ground water and oil and gas deposits, the application of such rules to nonrenewable ground water resources is easily conceivable. In some respects, one may argue that these rules are similar to the principle of reasonable and equitable use to the extent that both regimes mandate 
consultation, prior notification, and the exchange of data. Moreover, to the extent that states with interests in transboundary oil and gas deposits reach an agreement over the development of these resources, such agreement is based on various and competing state interests and factors akin to those considered under equitable and reasonable use.

Notwithstanding, water has often been described in relation to basic human necessity and even human rights that cannot be subjected solely to profit-based operations (Gleick 1999; Barlow 2003). In a typical marketplace transfer, only the buyer and seller have a legitimate interest in the commodity transferred. However, in the market transfer of a water resource, the list of potential claimants with legitimate interests in the use of the resource could far exceed the number of those holding water rights (Sax 1994; Diaz and Dubner 2001). As such, there are unique ethical considerations related to the commercialization and provision of fresh water resources.

In interpreting the International Covenant on Economic, Social and Cultural Rights, the U.N. Committee on Economic, Social and Cultural Rights (UNCESCR) formally declared that water is a human right (UN 2002). It asserted that " $[\mathrm{t}]$ he human right to water entitles everyone to sufficient, affordable, physically accessible, safe and acceptable water for personal and domestic uses." Moreover, it noted that states have the obligation to "fulfill" the right to water by undertaking measures that ensure the full realization of the right, including to those who are "unable, for reasons beyond their control, to realize that right themselves by the means at their disposal."

While not necessarily barring the possibilities of commercialized extraction of nonrenewable water resources, water regarded as a human right would significantly restrict the extent to which states could permit profitoriented exploitation. Each state would be bound to ensure that all of its citizens could realize their right to water, regardless of whether every citizen could afford that possibility (McCaffrey 1992). Accordingly, exploration and exploitation would be driven more by state obligation to provide for its citizenry than by the free market of supply and demand. In the case of a nonrecharging transboundary aquifer, the principle of equitable and reasonable use theoretically could assist in ensuring this state obligation, if factors considered in the analysis include social and economic needs and populations dependent on the resource.

Nevertheless, even from the UNCESCR declaration, it is unclear to what extent such a "right" applies (UN 2002). Is the right to water an actual entitlement to a certain quantity of water, i.e., to an amount necessary to sustain life, which would require the state to provide the water at all costs? Or is it merely a right to have access to fresh water, which might suggest that the state could delegate the provision of water to a profit-motivated entity? Furthermore, against whom would the right be enforceable? Would it be enforceable by a citizen only against that citizen's state, or could a citizen also enforce it against a coriparian state, notwithstanding the citizen's nationality?
The aforementioned discussion of the status of nonrecharging aquifers under international law clearly is far from definitive or comprehensive. It merely provides a starting point from which additional critical thought and dialogue may ensue. The need to delineate rules and norms to assist nations in the management and allocation of such resources, however, is clear. Although the extent of global reserves of fresh water stored in transboundary nonrecharging aquifers is uncertain, suffice it to say that it constitutes a highly important water source for many nations and is often the only viable source of fresh water (UN 2003).

\section{Concluding Remarks}

In this paper, we considered transboundary and international ground water resources and international law from a hydrogeologic perspective. The purpose of this study was, in part, to consider the legal implications stemming from various circumstances when ground water resources traverse international political boundaries. A critical component of this discussion is the six conceptual models offered as illustrative of the main scenarios in which ground water resources can have transboundary consequences. The models, which are based on principles of hydrogeology and actual examples, are intended to serve as generic templates against which to assess existing and proposed international norms for transboundary and international ground water resources. We hope that they will prove useful as tools in water management decision making, affecting transboundary and international ground water resources. To be fully understood, however, and if they are to provide useful information, their analysis and interpretation must be developed in the proper scientific context-based on a sound understanding of the science of ground water.

In addition, this study emphasized the need to further clarify the status of international law as it applies to transboundary and international ground water resources. Ground water today is the single most indispensable substance for sustaining growing populations as well as nourishing economic development. Yet, the rules governing the use, allocation, conservation, and overall management of this resource across borders are still unclear. The Watercourse Convention is a significant milestone in the development of international law, especially to the extent that it supports the application of international water law principles, like the doctrine of hydrological unity, reasonable and equitable use, no substantial harm, cooperation, and good faith negotiations, to certain types of transboundary and international ground water resources. While certainly a positive development, the convention still leaves many questions unanswered. Most prominent of these is the question of which law to apply to aquifers unrelated hydraulically to any surface body of water, or to nonrenewable ground water resources?

Finally, this study was intended to infuse the science of ground water into the development, interpretation, and application of international legal concepts and norms relevant to transboundary and international ground water 
resources. There is presently a dearth of scientific knowledge among government officials, legislators, policymakers, jurists, and legal scholars about ground water. This is especially evident in the treatment afforded to ground water resources in past international agreements and academic writings and may be a principal reason for the incompleteness of the Watercourse Convention.

Decision makers and lawyers alike must develop a stronger understanding of hydrogeological terms and processes so as to overcome common misconceptions, mislabeling, and general misunderstanding about water resources. The absence or ignorance of this basic knowledge, in many respects, has resulted in the poor management of scarce water resources throughout the world; at times, it has resulted in serious harm to people and the environment. While not a panacea, the inclusion and understanding of underlying science in the decision-making process can serve to achieve more balanced, scientifically based, and thoughtful decisions. Only through a full understanding of the various legal and policy issues, as well as the underlying science involved, can states use, manage, and protect their transboundary and international resources prudently and effectively and in such a way that the resources provide adequately for both present and future generations.

\section{References}

Abbotsford-Sumas Aquifer International Task Force. n.d. http:// wlapwww.gov.bc.ca/wat/aquifers/absumas.html.

Accord Entre L'Égypte et L'Italie Concernant L'Établissement des Frontières entre La Cyrénaïque et L'Égypte, Dec. 6, 1925, Egypt-Italy. Reprinted in: Legislative Texts and Treaty Provisions Concerning the Utilization of International Rivers for Other Purposes than Navigation. U.N. Doc. ST/LEG/SER.B/12; Sales No. 63.v.4 (1963).

Agreement between the Government of the Federal People's Republic of Yugoslavia and the Government of the Hungarian People's Republic Together with the Statute of the YugoslavHungarian Water Economy Commission, Aug. 8, 1955, Yugoslavia-Hung. Reprinted in: Legislative Texts and Treaty Provisions Concerning the Utilization of International Rivers for Other Purposes than Navigation. U.N. Doc. ST/LEG/ SER.B/12; Sales No. 63.v.4 (1963).

Agreement between the Government of the Federal People's Republic of Yugoslavia and the Government of the People's Republic of Albania Concerning Water Economy Questions, Together with the Statute of the Yugoslav-Albanian Water Economic Commission and with the Protocol Concerning Fishing and Frontier Lakes and Rivers, Dec. 5, 1956. Yugoslavia-Alb. Reprinted in: Legislative Texts and Treaty Provisions Concerning the Utilization of International Rivers for Other Purposes than Navigation. U.N. Doc. ST/LEG/SER.B/12; Sales No. 63.v.4 (1963).

Agreement Concerning Frontier Rivers, Fin.-Swed. 825 U.N.T.S. 191 (Sept. 16, 1971).

Agreement Concerning the Use of Water Resources in Frontier Waters, Czech Rep.-Pol. 523 U.N.T.S. 89 (Mar. 21, 1958).

Agreement Concerning Water Economy Questions Government of the Federal People's Republic of Yugoslavia and the Government of the People's Republic of Bulgaria, Apr. 4, 1958, Yugoslavia-Bulg. Reprinted in: Legislative Texts and Treaty Provisions Concerning the Utilization of International Rivers for Other Purposes than Navigation. U.N. Doc. ST/LEG/SER.B/12; Sales No. 63.v.4 (1963).
Agreement Confirming Minute No. 242 of the International Boundary and Water Commission, U.S.-Mex. 24 U.N.T.S. 1968 (Aug. 30, 1973).

Almássy, E., and Zs. Busás. 1999. Inventory of Transboundary Ground Waters. U.N./E.C.E. Task Force on Monitoring \& Assessment, Guidelines on Transboundary Ground Water Monitoring, Lelystad, The Netherlands, U.N. Sales No. 9036952743; vol. 1 of 4 .

Anderson, R.C. 1998. Environmental policy and technical project: New independent states: The management of international rivers and lakes, prepared for Central Asia Mission, USAW, Almaty, Kazakhstan.

Arias, H.M. 2000. International groundwaters: The Upper San Pedro River basin case. Natural Resources Journal 40, no. 2: 199-217.

Arrangement on the protection, utilization, and recharge of the Franco-Swiss Genevese aquifer, Fr.-Switz. 1977. http:// www.internationalwaterlaw.org/RegionalDocs/Franko-SwissAquifer.htm (accessed February 7, 2005).

Barberis, J.A. 1986. International ground water resources law. Food and Agricultural Organization Legislative Study 40, 67.

Barlow, M. 2003. Globalization of water as a commodity is destroying resources. U.S. Water News, 9.

Bouwer, H. 1978. Groundwater Hydrology. New York: McGraw Hill College.

Burchi, S. 1999. National regulation for groundwater: Options, issues and best practices. In Groundwater: Legal and Policy Perspectives, Proceedings of a World Bank Seminar, ed. Salman M.A. Salman, 55-67. Washington, DC: World Bank.

Caponera, D.A. 1992. Principles of Water Law and Administration: National and International. Rotterdam: A.A. Balkema.

Caponera, D.A., and D. Alhéritière. 1978. Principles for international ground water law. Natural Resources Joumal 18, no. 3: 589-619.

Civic, M.A. 1998. A comparative analysis of the Israeli and Arab water law traditions and insights for modern water sharing agreements. Denver Joumal of International Law \& Policy 26, no. 3: 437-450.

Convention and statutes relating to the development of the Chad Basin, May 22, 1964. Natural Resources Water Series 13. http://ocid.nacse.org/qml/research/tfdd/toTFDDdocs/128ENG. htm (accessed February 7, 2005)

Convention concerning the protection of Italo-Swiss waters against pollution, Switz.-Italy, 957 U.N.T.S. 280 (Apr. 20, 1972).

Convention Entre L'Union des Républiques Socialistes Soviétiques et La Turque pour la Jouissance des Eaux Limitrophes et Protocolo Concernant la Rivière Araxe, Jan. 8, 1927, Turk.-U.S.S.R. Reprinted in: Legislative Texts and Treaty Provisions Concerning the Utilization of International Rivers for Other Purposes than Navigation. U.N Doc. ST/LEG/SER.B/12; Sales No. 63.v.4 (1963).

Dellapenna, J.W. 2001. The evolving international law of transnational aquifers. In Management of Shared Ground Water Resources: An Israeli-Palestinian Case with an International Perspective, ed. E. Feitelson and M. Haddad, 209257. Kluwer Academic.

Dellapenna, J.W. 1992/1994. Designing the legal structures of water management needed to fulfill the Israeli-Palestinian declaration of principles. Palestinian Yearbook of International Law 7, 63-103.

Diaz, L.M., and B.H. Dubner. 2001. The necessity of preventing unilateral responses to water scarcity-The next major threat against mankind this century. Cardozo Journal of International and Comparative Law 9, no. 1: $1-40$.

Eckstein, G.E. 1995. Application of international water law to transboundary ground water resources, and the SlovakHungarian dispute over Gabcikovo-Nagymaros. Suffolk Transnational Law Review 19, no. 1: 67-116.

Eckstein, G.E., and Y. Eckstein. 2003. Ground water resources and international law in the Middle East process. Water International 28, no. 2: 154-161. 
FAO AQUASTAT: UN Food and Agriculture Organization. n.d. http://www.fao.org/ag/agl/aglw/aquastat/countries/Iraq.

Fuentes, X. 1999. The utilization of international groundwater in general international law. In The Reality of International Law: Essays in Honor of Ian Brownlie, ed. G.S. GoodwinGill and S. Talmon, 177-198. Oxford University Press.

Gleick, P. 1999. The human right to water. Water Policy 1, no. 5: 487-503. http://www.pacinst.org/reports/basic_water_needs/ human_right_to_water.pdf.

Hayton, R.D. 1981. The ground water legal regime as instrument of policy objectives and management requirements. In International Groundwater Law, ed. L.A. Teclaff and A.E. Utton. 57-75. Oceana Publications.

Hayton, R., and A.E. Utton. 1989. Transboundary ground waters: The Bellagio Draft Treaty. Natural Resources Journal 28, no. 2: 663-722.

Hebard, E.M. 2000. A focus on a binational watershed with a view toward fostering a cross-border dialogue. Natural Resources Joumal 29, no. 3: 281-321.

Hibbs, B.J., B.K. Darling, and I.C. Jones. 1998. Hydrogeological regimes of arid-zone aquifers beneath low-level radioactive waste and other waste repositories in TransPecos, Texas and Northern Chihuahua, Mexico. In Gambling with Groundwater-Physical, Chemical, Biological Aspects of Aquifer-Stream Relations, Proceedings of Joint 27th IAH Congress and AIH Annual Meeting, ed. J.V. Brahana, Y. Eckstein, L.K. Ongley, R. Schneider, and J.E. Moore, 311-322. St. Paul, MN: American Institute of Hydrology.

International Boundary and Water Commission. 1998. Transboundary aquifers and binational ground-water data base, City of El Paso/Ciudad Juárez Area. http://www.ibwc. state.gov/html/body_body_binational_waters.htm (accessed February 7,2005).

International Law Association. 1987. The Seoul Rules on international groundwaters. http://www.internationalwaterlaw. org/intldocs/seoul_rules.htm (accessed February 7, 2005).

International Law Association. 1966. Helsinki Rules on the uses of the waters of international rivers and comments. http:// www.internationalwaterlaw.org/IntlDocs/Helsinki_Rules.htm (accessed February 7, 2005).

Kemper, K.E., L. Amore, and E. Feitelson. 2003. Management of the Guarani aquifer system: Moving towards the future. Water International 28, no. 2: 198-200.

Krishna, R., and M.A. Salman. 1999. International groundwater law and the World Bank policy for projects on transboundary groundwater. In Groundwater: Legal and Policy Perspectives, Proceedings of a World Bank Seminar, ed. Salman M.A. Salman, 163-189. Washington, DC: World Bank.

LaMoreaux, P.E., B.A. Memon, and H. Idris. 1985. Groundwater development, Kharga Oases, Western Desert of Egypt: A long-term environmental concern. Environmental Geology and Water Sciences 7, no. 2: 129-149.

McCaffrey, S. 1999. International ground water law: Evolution and context. In Groundwater: Legal and Policy Perspectives, Proceedings of a World Bank Seminar, ed. Salman M.A. Salman, 139-161. Washington, DC: World Bank.

McCaffrey, S. 1992. A human right to water: Domestic and international implications. Geo. Int'l Envtl. L. Rev. 5, no. 1: $1-24$.

McCaffrey, S. 1991. Seventh report on the law of the nonnavigational uses of international watercourses, U.N. Doc. A/CN.4/436. Reprinted in: [1991] 2 Y.B. Int'1 L. Comm'n 45, U.N.Doc. A/CN.4/SER.A/1991/Add.1 (Part 1), pp. $45-69$.

Mijatovic, B.F. 1998. Prevention of over-exploitation of deep aquifers in Vojvodina, Northern Yugoslavia. In Gambling with Groundwater-Physical, Chemical, Biological Aspects of Aquifer-Stream Relations, Proceedings of Joint 27th IAH Congress and AIH Annual Meeting, ed. J.V. Brahana, Y. Eckstein, L.K. Ongley, R., Schneider, and J.E. Moore, 353-358. St. Paul, MN: American Institute of Hydrology.
Mumme, S. 2000. Minute 242 and beyond: Challenges and opportunities for managing transboundary ground water on the Mexico-U.S. Border. Natural Resources Journal 40, no. 2: 341-362.

Murray, C.R., and E.B. Reeves. 1977. Estimated use of water in the United States in 1975. USGS Circular 765. Washington, DC: USGS.

Pedrazzini, C., and J.T. Teyssier. 1986. Hydrocarbon deposits of the border region between Mexico and the United States and potential exploitation problems in transboundary deposits: A preliminary report. Natural Resources Journal 26 , no. 4: 695-710.

Sax, J.L. 1994. Understanding transfers: Community rights in the privatization of water. West-Northwest Joumal of Environmental Law and Policy 1, no. 1: 13-16.

State Treaty between the Grand Duchy of Luxembourg and the Land Rhineland-Palatine in the Federal Republic of Germany Concerning the Construction of a Hydroelectric power-plant on the Sauer (Sûre) at Rosport/ Ralingen, Apr. 25, 1950, F.R.G.-Lux. Reprinted in: Legislative Texts and Treaty Provisions Concerning the Utilization of International Rivers for Other Purpose than Navigation, U.N. Doc. ST/LEG/SER.B/12; Sales No. 63.v.4 (1963).

Sultan, M., N.C. Sturchio, R. Becker, N. Manocha, and A. Milewski. 2004. Paleodrainage networks of the Nubian Aquifer system revealed from SIR-C and SRTM Data. Geological Society of America Abstracts 35, no. 1: 67.

Sydykov, G.S., and V.V. Veselov. 1993. Water ecological situation changes of the Aral Sea Basin under the influence of intensive agricultural development. In Environmental Impact of Agricultural Activities, ed. Y. Eckstein and A. Zaporozec, pp. 3-8. Proceedings of Industrial and Agricultural Impacts on the Hydrologic Environment, the Second USA/CIS Joint Conference on Environmental Hydrology and Hydrogeology, Alexandria, VA: American Institute of Hydrology and Water Environment Federation.

Székely, A. 1986. The international law of submarine transboundary hydrocarbon resources: Legal limits to behavior and experiences for the Gulf of Mexico. Natural Resources Journal 26, no. 4: 733-766.

Teclaff, L.A., and E. Teclaff. 1979. Transboundary ground water pollution: Survey and trends in treaty law. Natural Resources Journal 19, no. 3: 629-667.

Traité de Paix Entre les Puissance Halléis et Asocies, d'Une Part, et L'Italie, d'Autre Part, Feb. 10, 1947. Reprinted in: Legislative Texts and Treaty Provisions Concerning the Utilization of International Rivers for Other Purposes than Navigation, U.N. Doc. ST/LEG/SER.B/12; Sales No. 63.v.4 (1963).

Tujchneider, O., M.A. Perez, M.C. Paris, and M.P. D'Elia. 2003. The Guarani Aquifer system: A resource shared by four countries. Geol. Soc. Am. Abstr 35, 198.

UN. 2003. Water for people, water for life; the United Nations World Water Development Report, U.N. Sales No. 92-3-103881-8. Barcelona, Spain: UNESCO/Bergahn Books.

UN. 2002. Substantive issues arising in the implementation of the international covenant on economic, social and cultural rights, U.N. ECOSOC, 29th Sess., General Comment No. 15 at 1, U.N. Doc. E/C.12/2002/11. United Nations Economic and Social Council.

UN. 1997. Convention on the non-navigational uses of international watercourses, G.A. Res. 51/229, U.N. GAOR, 51st Sess., U.N. Doc. A/RES/51/229 (1996).

UN. 1994. Resolution on confined transboundary groundwater 2 Y.B. International Law Commission 135, U.N. Doc. A/ CN.4SER.A/1994/Add.1 (Part 2)

Utton, A.E. 1982. The development of international groundwater law. Natural Resources Journal 22, no. 1: 95-117.

Utton, A.E., and P.D. McHugh. 1986. On an institutional arrangement for developing oil and gas in the Gulf of Mexico. Natural Resources Journal 26, no. 4: 717-732. 
Wohlwend, B.J. 2002. Workshop on harmonization of divetging interests in the use of shared water resources, an overview of groundwater in intemational law, a case study: The FrancoSwiss Genevese Aquifec. htt://wwwwbjwconsult.com/The\% 20Genevese\% 20Aquiferpdf (accessed February 7, 2005).
Yamada, C. 2003. Shared natural resources: Addendum to the first report on outlines, U.N. GAOR, 55th Sess., 533d intg. at 5-6, para. 13 U.N. Doc. A/CN.4/533/Add.1. http:// www un org/law/ilc/sessions/55/55docs.htm (accessed February 7,2005 ).

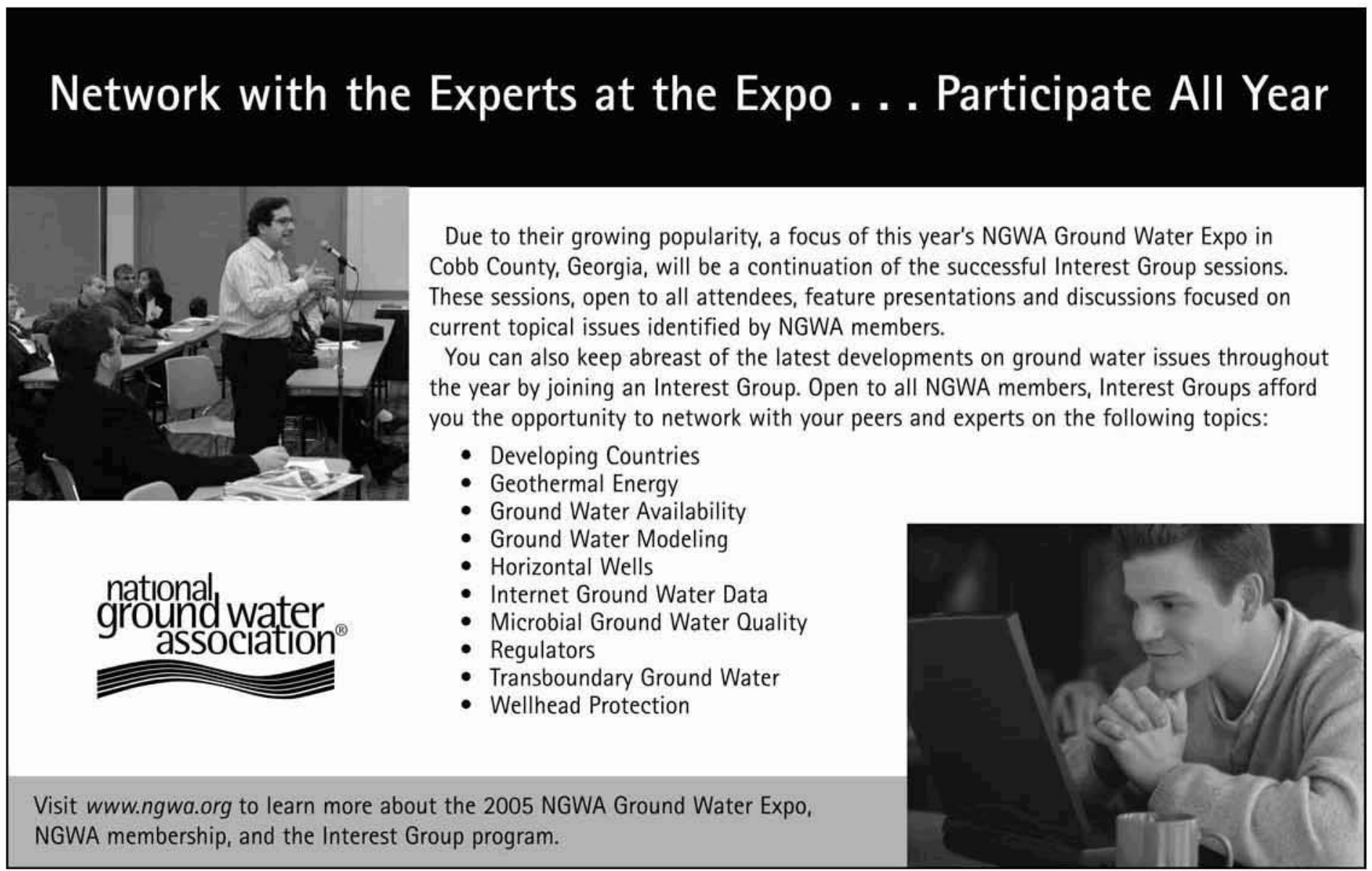

